\title{
Aquatic insects in an estuarine environment: densities, distribution and salinity tolerance
}

\author{
D. DUDLEY WILLIAMS*† AND NANCY E. WILLIAMS* \\ †School of Biological Sciences, University of Wales, Bangor, Gwynedd LL57 2UW, U.K. \\ $\ddagger$ Institute of Earth Studies, University of Wales, Aberystwyth, Dyfed SW23 3DB, U.K. \\ *Address for correspondence: Division of Life Sciences, University of Toronto at Scarborough, 1265 Military Trail, \\ Scarborough, Ontario, Canada M1C 1A4
}

\section{S U M M A R Y}

1. Aquatic insects were quantitatively surveyed at five sites along the tidally influenced section of a river-dominated estuary in North Wales. Site 1 was the furthest upstream and was established as a reference site as it was never inundated by salt water. Site 5 was the furthest downstream and was inundated by all incoming tides. Numerically, insects made up $32 \%$ of the estuarine invertebrate fauna.

2. Although the densities of most insect taxa decreased towards the estuary mouth, there were significant numbers present downstream for much of the year; for example, in April at site 4 (which was inundated by $81 \%$ of all high tides), a mean of 3514 chironomid larvae were recorded per $\mathrm{m}^{2}$ of estuary bed. Even at site 5 , which was inundated twice daily, there were 747 larvae per $\mathrm{m}^{2}$. Among the larger aquatic insects, caddisfly and elmid beetle larvae, together with stonefly nymphs, were consistently taken at site 4 (e.g. maxima of forty-eight caddisfly larvae $\mathrm{m}^{-2}$ in December and seventy elmids $\mathrm{m}^{-2}$ in April), although their densities were lower than upstream.

3. There were seasonal shifts in the longitudinal distribution of several taxa, most notably the extension of chironomids down the estuary in April and July, and the concentration of simuliid larvae and mayfly nymphs at site 2 in July. The total freshwater benthos showed a downstream shift between September and December, which was maintained through April and into the summer. The latter was despite peak saltwater inundation (highest tides) in October, November and April. In June and July, when saltwater intrusion was lowest, the ranges of many aquatic insects had contracted to sites 1 and 2.

4. Laboratory experiments showed that virtually all individuals of nineteen species of insects collected from site 1 (freshwater) survived a 4 -h immersion in $8.75 \%$ o saltwater ( $25 \%$ strength seawater). Immersion in progressively more saline solutions reduced the survivorship of first the mayflies, followed by the caddisflies Glossosoma conformis and Hydropsyche instabilis. After $4 \mathrm{~h}$ in full strength seawater, all specimens of the stonefly Dinocras cephalotes, over half of the Perla bipunctata, and some individuals of nine species of caddisfly were alive. Four species of caddisfly (Sericostoma personatum, Odontocerum albicorne, Potamophylax cingulatus and Adicella reducta) survived a 24-h simulated tidal cycle of immersion. With the exception of P. cingulatus, a few individuals of these caddisfly species survived immersion in full-strength seawater for $24 \mathrm{~h}$. For some individual species there was good agreement between their observed longitudinal distribution in the estuary and laboratory-measured salinity tolerance; however, there was no significant correlation, overall, for the fauna. 


\section{Introduction}

Insects have achieved unparalleled success in both terrestrial and freshwater environments, with the numbers of species in these two habitats approximating several million and more than 30000 , respectively (Williams \& Feltmate, 1992). The one major environment in which they appear not to be well represented is the sea, as the number of species that can be called 'marine' amounts to only several hundred. As the oceans cover approximately $75 \%$ of our planet's surface, it is surprising that insects, with their approximately 300 million years of evolution, are not more common in saline habitats. Apart from the hemipteran genus Halobates, no insects are known from the open ocean, the majority of marine insects being associated with coastal habitats, such as saltmarshes, mangroves, decaying seaweed on the seashore, and estuaries (Axtell, 1976; Dobson, 1976; Cheng, 1985).

Few attempts have been made to survey and study insects in marine habitats by either marine or freshwater biologists. This has led, even recently, to statements such as 'insect dominance ... . extends no further into the marine environment than the high tide mark' (Gullan \& Cranston, 1994). Although some brackishwater studies have recorded the presence of immature stages of insects (e.g. McIntyre \& Eleftheriou, 1968; Healey, 1982; Mees, Dewicke \& Hamerlynck, 1993), they typically have lumped insects into large taxonomic bins (e.g. Insecta, Diptera, Coleoptera) of limited use to entomologists.

The study reported here is concerned with the insects found living in a tidally influenced river in North Wales, and presents details of: (i) their distribution among sites variously inundated by the sea; (ii) seasonal changes in their population densities; and (iii) the salinity responses of individual species. The drift dynamics of these insects into the lower estuary and their consumption by estuarine consumers have been documented elsewhere (Williams \& Williams, 1998.

\section{Study site}

The Afon Aber, located in the county of Gwynedd, North Wales $\left(54^{\circ} 14^{\prime} \mathrm{N}, 4^{\circ} 00^{\prime} \mathrm{W}\right)$, arises in the Carneddau mountain range. Its catchment extends to an area of some $24.5 \mathrm{~km}^{2}$ and the watercourse itself comprises eighty-two first-order streams, thirteen second-order streams, three third-order streams and one fourthorder stream. The bedrock underlying the catchment is overlain with Quaternary drift. The upper Aber Valley is composed of boulder clay, whereas the valley floor is made up largely of fluvio-glacial sand and gravel. Alluvium is present near the estuary mouth. Soils in the area reflect a transition from upland peat to loam and silt in the lowland, and originate from Palaeozoic siltstone, mudstone and slate rocks (Brown, 1960; Bassett, 1967; Stocks, 1988). The upper reaches of the catchment are common lands supporting rough grazing for sheep. Further down there are, successively, areas of coniferous plantation, the village of Aber, flat pasture and finally saltmarsh.

The Aber Estuary is of the freshwater-dominated, stratified type, with freshwater flow rates varying annually between about 30 and $110 \mathrm{~cm} \mathrm{~s}^{-1}$. Incoming tides push a visible (semi-opaque) saltwater wedge upstream along the surface of the bed and this creates a layer of saline water that envelops the benthic habitat. Monitoring of salinity levels on both rising and ebb tides showed that very little mixing occurs between the wedge and the overlying freshwater. At the extreme edge of the wedge front (typically around 5-10 cm thick) salinity ranged between 8 and 17\%. Tides along this stretch of the Gwynedd coast are of the semidiurnal type, and the maximum annual tidal range is of the order of $10 \mathrm{~m}$. Benthic organisms on the estuary bed are thus subject to saltwater inundation twice daily.

\section{Materials and methods}

Five sampling stations, each characterized by a different degree of saltwater inundation, were set up along the estuary (Fig. 1). They were:

1 at a point $5 \mathrm{~m}$ upstream of the maximum intrusion of the highest spring tide (extreme high water mark, EHWM, = $10.2 \mathrm{~m}$ ); here the benthic fauna was exposed only to freshwater;

2 at the $9.1 \mathrm{~m}$ mark; here the benthos was inundated by $33.7 \%$ of all high tides;

3 at the $8.4 \mathrm{~m}$ mark which, in this region, represented the level of the mean high water mark (MHWM); here benthos was inundated by $50 \%$ of all high tides; 4 at the $7.6 \mathrm{~m}$ mark; inundated by $80.9 \%$ of all high tides;

(C) 1998 Blackwell Science Ltd, Freshwater Biology, 39, 411-421 


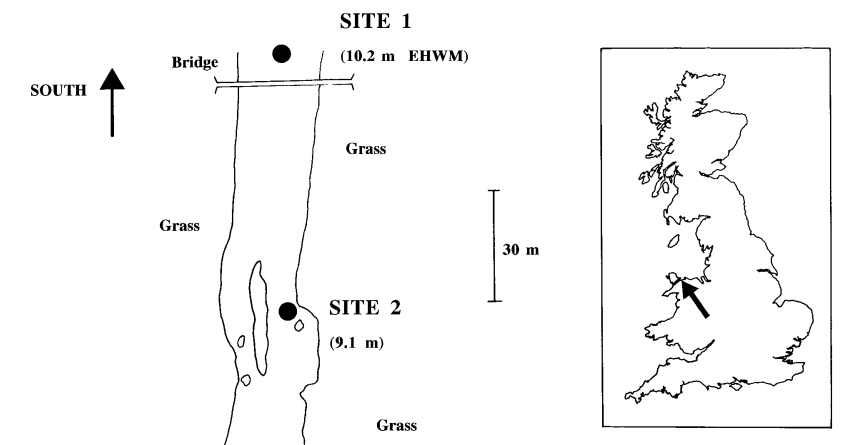

tides inundated this site in April, compared with only $45 \%$ in June.

At sites $1-3$, the substratum was typically riverine, comprising cobbles (up to $30 \mathrm{~cm}$ in diameter), stones, coarse and fine gravels, and coarse sand. At site 4 there was much more sand, and at site 5 the substratum was almost entirely sand. Whereas there was evidence of occasional water-induced bed disturbance at these latter two sites, the substratum at the three uppermost sites remained largely undisturbed over the entire study period.

Each site was sampled for benthic invertebrates at 3-monthly intervals over the period September 1990 to July 1991. Samples were taken to a substrate depth of $5 \mathrm{~cm}$, using a $250 \mu \mathrm{m}$ mesh Surber Sampler with a sampling area of $900 \mathrm{~cm}^{2}$. Three, randomly positioned, replicate samples were taken at each site, starting, on each occasion, at site 5 and working upstream. Samples were preserved in $95 \%$ ethanol in the field. In the laboratory, the samples were rinsed with tap-water, floated in saturated calcium chloride solution (to help separate the animals from the inorganic substrate), and examined under a dissecting microscope. Individual animals were removed from the surrounding detritus, identified and preserved in $75 \%$ ethanol.

In addition to these samples, on seven occasions during 1990-91 additional sampling of caddisflies (Trichoptera) was undertaken at the five sites. This involved two people turning over rocks and gravel in order to look for the larvae and pupae of these insects adhering to the margins and undersides. On each occasion, about $45 \mathrm{~min}$ was spent collecting caddisflies at each site, beginning downstream.

For the salinity tolerance trials, which were run from January to March 1991, insects were freshly fieldcollected from site 1 which was above the EHWM. They were transported and maintained in cool (river temperature), well oxygenated, river water. Collecting test insects solely from site 1 ensured that, as far as could be acertained and barring extensive migration from downstream, they had experienced little or no prior exposure to saltwater. Whereas this meant that it was not possible to assess the capacity for acclimation to salinity, it did serve to standardize the insects, a factor deemed to be more important in the context of this study. Natural seawater was used for the trials but as, in this region, salinity ranges between 29 and $33 \%$, it was concentrated (by evaporation and aeration) to provide a $35 \%$ stock solution. 
In the salinity trials, batches of 5-10 animals per species were subjected to four salinity levels (8.75, $17.5,26.25$ and $35.0 \%$; prepared from the stock solution and river water) for between 1 and $4 \mathrm{~h}$. The procedure was as follows: the animals were transferred into 15$\mathrm{cm}$-diameter glass bowls in which there was a $5 \mathrm{~cm}$ depth of water over a $0.5 \mathrm{~cm}$ layer of clean, coarse, non-marine sand substrate. A slight clockwise current (approximately $4 \mathrm{~cm} \mathrm{~s}^{-1}$ ) and aeration were provided in each bowl by means of air pumped through a glass pipette fastened to the inside of the bowl wall. Because of the different salinities used, it was difficult to standardize immersion. The protocol employed was first to transfer all batches from 'pure' river water to bowls containing river water to which sufficient natural seawater had been added to create a salinity of $4.4 \%$. Such exposure was meant to simulate the incoming tide for the test animals. After $15 \mathrm{~min}$, the insects were transferred to new bowls containing one of the four salinity trial levels. The condition (in terms of behaviour, activity and whether they were alive or dead) of each individual was monitored at $15 \mathrm{~min}$ intervals for the first hour and at $30 \mathrm{~min}$ intervals for the next $3 \mathrm{~h}$. After a total of $4 \mathrm{~h}$ (calculated as being the average maximum time they would probably be immersed by the tide in the Aber Estuary), all animals were transferred back into river water and their condition was assessed after a further $20 \mathrm{~h}$. Transfer of insects from the $15 \mathrm{~min}$ 'acclimatization' bowls took place, always, at around $10.00 \mathrm{~h}$, and this established time 0 . Throughout monitoring, the bowls were kept under constant dim light conditions (approximately $10 \times 10^{13}$ quanta $\mathrm{s}^{-1} \mathrm{~cm}^{-2}$ ) and at a temperature of $10-15^{\circ} \mathrm{C}$.

A few species were selected for two additional trials. In the first, insects were immersed in river water for $8 \mathrm{~h}$, then in full strength seawater for $4 \mathrm{~h}$, then in river water for $8 \mathrm{~h}$, and again in seawater for $4 \mathrm{~h}$; this was meant to approximate a diel tidal cycle. In the second trial, they were immersed, continuously, in 35.0\% for $24 \mathrm{~h}$ in order to test for extreme tolerance.

The sizes of specimens used in these trials varied slightly according to collecting time (January-March) and availability in the field. In order to reduce variation in response to salinity that might have been size dependent, whenever possible, individuals from the modal size class present in the field at the time of collection were used.

\section{Results}

Whereas the densities of most insect taxa dropped substantially downstream from site 1, there were significant numbers present further down the estuary at certain times of the year (Table 1); for example, the densities of chironomid larvae at sites 1 and 3 were not significantly different in either April or July (April: $481.0 \pm 106.9$ and $576.7 \pm 49.5$ larvae $900 \mathrm{~cm}^{-2}$; July: $565.7 \pm 128.8$ and $507.7 \pm 38.4$ larvae $900 \mathrm{~cm}^{-2}$; Student's $t$-test $=-0.81$ and 0.43 , respectively; $P>0.4$ ). Furthermore, in April, at site 4 (inundated by $81 \%$ of all high tides), a mean of $316.3 \pm 41.4$ chironomid larvae was recorded on only $900 \mathrm{~cm}^{2}$ of estuary bed $\left(3514 \mathrm{~m}^{-2}\right)$. Even at site 5 , inundated by all high tides, there were $67.3( \pm 31.1)$ larvae $900 \mathrm{~cm}^{-2}\left(747 \mathrm{~m}^{-2}\right)$. Among the larger aquatic insects, caddisfly and elmid beetle larvae together with stonefly nymphs were consistently taken at site 4 , although their densities were lower; for example a maximum of $4.3 \pm 1.2$ caddisfly larvae $900 \mathrm{~cm}^{-2}$ in December and $6.3 \pm 1.9$ elmids $900 \mathrm{~cm}^{-2}$ in April (forty-eight and seventy individuals $\mathrm{m}^{-2}$, respectively).

\section{Detailed consideration of the taxa}

Identification of the larval chironomids revealed a decrease in species richness towards the more seaward sites. At site 1 in September for example, five species were abundant or common (defined as $>30$ and 1030 specimens $900 \mathrm{~cm}^{-2}$ of substrate, respectively), four orthoclads: Eukiefferiella clypeata, Tvetenia sp., Orthocladius (Orthocladius) sp. and Brillia modesta; and Rheotanytarsus sp. (Tanytarsini). Of these, E. clypeata and Orthocladius (O.) sp. were common also at site 3. At site 1 in April, Orthocladius (Euorthocladius) thienemanni, E. clypeata, Corynoneura sp., Rheotanytarsus sp. and Polypedilum sp. were common or abundant. At site 2, E. clypeata, B. modesta and Polypedilum sp. predominated. Eukiefferiella clypeata and Orthocladius (O.) sp. were abundant at site 3 but, at sites 4 and 5 , only Orthocladius (O.) sp. and Orthocladius (E.) thienemannia persisted in any numbers.

Larvae of the elmid beetle species Elmis aenea, Esolus parallelepipedus and Limnius vokkman were common to abundant at sites 1 and 2 throughout most of the year. However, only the first two species were found, in small numbers, at sites 3 and 4 . The longitudinal distributions of larval caddisfly species, mayfly and

(C) 1998 Blackwell Science Ltd, Freshwater Biology, 39, 411-421 
Aquatic insects in an estuarine environment

Table 1 Densities of insects $\left(\times 900 \mathrm{~cm}^{-2}, \pm 1 \mathrm{SE}\right)$ collected from the bed of the Aber Estuary on four occasions during the year

\begin{tabular}{|c|c|c|c|c|c|}
\hline Taxa & Site 1 & Site 2 & Site 3 & Site 4 & Site 5 \\
\hline \multicolumn{6}{|l|}{ September } \\
\hline Plecoptera & $17.0 \pm 8.5$ & 0 & 0 & $0.7 \pm 0.7$ & $0.3 \pm 0.3$ \\
\hline Ephemeroptera & $209.0 \pm 39.4$ & $0.7 \pm 0.7$ & $0.3 \pm 0.3$ & 0 & 0 \\
\hline Trichoptera & $171.0 \pm 45.7$ & $0.7 \pm 0.7$ & $0.3 \pm 0.3$ & 0 & 0 \\
\hline Elmidae & $140.7 \pm 53.7$ & $21.7 \pm 6.3$ & $1.3 \pm 1.3$ & $0.3 \pm 0.3$ & $1.3 \pm 1.3$ \\
\hline Gyrinidae & $12.7 \pm 3.8$ & $0.7 \pm 0.7$ & 0 & 0 & 0 \\
\hline \multicolumn{6}{|l|}{ Simuliidae } \\
\hline larvae & $29.3 \pm 12.7$ & $1.6 \pm 1.2$ & $0.7 \pm 0.7$ & 0 & 0 \\
\hline pupae & 0 & 0 & 0 & 0 & 0 \\
\hline \multicolumn{6}{|l|}{ Chironomidae } \\
\hline larvae & $3892.3 \pm 454.7$ & $915.3 \pm 261.2$ & $349.0 \pm 23.4$ & $5.6 \pm 2.6$ & $1.0 \pm 0.6$ \\
\hline pupae & $18.0 \pm 10.3$ & $26.7 \pm 7.0$ & $16.0 \pm 1.5$ & $0.7 \pm 0.7$ & 0 \\
\hline Other Diptera & $34.0 \pm 5.0$ & $5.3 \pm 2.9$ & 0 & 0 & 0 \\
\hline \multicolumn{6}{|l|}{ December } \\
\hline Plecoptera & $101.7 \pm 43.2$ & $44.3 \pm 18.7$ & $3.0 \pm 2.1$ & $1.7 \pm 1.2$ & $0.3 \pm 0.3$ \\
\hline Ephemeroptera & $178.3 \pm 62.6$ & $28.0 \pm 11.0$ & $1.3 \pm 0.3$ & $0.3 \pm 0.3$ & $0.3 \pm 0.3$ \\
\hline Trichoptera & $98.3 \pm 44.3$ & $38.7 \pm 14.5$ & $13.0 \pm 1.5$ & $4.3 \pm 1.2$ & $2.0 \pm 1.5$ \\
\hline Elmidae & $5.7 \pm 3.2$ & $9.3 \pm 4.4$ & $1.0 \pm 0.6$ & $1.0 \pm 1.0$ & 0 \\
\hline Gyrinidae & $3.7 \pm 1.7$ & $2.0 \pm 1.5$ & 0 & $0.3 \pm 0.3$ & 0 \\
\hline \multicolumn{6}{|l|}{ Simuliidae } \\
\hline larvae & $47.0 \pm 24.0$ & $2.7 \pm 1.2$ & $0.3 \pm 0.3$ & 0 & 0 \\
\hline pupae & 0 & 0 & 0 & 0 & 0 \\
\hline \multicolumn{6}{|l|}{ Chironomidae } \\
\hline larvae & $250.0 \pm 107.1$ & $101.7 \pm 43.3$ & $45.3 \pm 8.4$ & $6.7 \pm 1.7$ & $4.0 \pm 2.0$ \\
\hline pupae & 0 & $0.3 \pm 0.3$ & 0 & 0 & 0 \\
\hline Other Diptera & $7.0 \pm 3.1$ & $1.3 \pm 0.9$ & $1.3 \pm 0.9$ & $0.7 \pm 0.7$ & $0.3 \pm 0.3$ \\
\hline \multicolumn{6}{|l|}{ April } \\
\hline Plecoptera & $43.7 \pm 3.9$ & $58.3 \pm 28.4$ & $7.7 \pm 0.3$ & $1.7 \pm 0.7$ & 0 \\
\hline Ephemeroptera & $210.3 \pm 31.8$ & $53.0 \pm 13.3$ & $4.7 \pm 2.6$ & 0 & 0 \\
\hline Trichoptera & $73.3 \pm 6.7$ & $71.3 \pm 10.2$ & $17.3 \pm 6.6$ & $2.3 \pm 1.2$ & 0 \\
\hline Elmidae & $32.3 \pm 5.2$ & $16.7 \pm 4.3$ & $6.0 \pm 1.2$ & $6.3 \pm 1.9$ & $2.0 \pm 0.6$ \\
\hline Gyrinidae & $2.7 \pm 1.2$ & $1.7 \pm 0.9$ & $0.3 \pm 0.3$ & $0.7 \pm 0.7$ & $0.3 \pm 0.3$ \\
\hline \multicolumn{6}{|l|}{ Simuliidae } \\
\hline larvae & $11.7 \pm 8.3$ & $1.3 \pm 0.3$ & 0 & 0 & 0 \\
\hline pupae & 0 & 0 & 0 & 0 & 0 \\
\hline \multicolumn{6}{|l|}{ Chironomidae } \\
\hline larvae & $481.0 \pm 106.9$ & $407.3 \pm 30.5$ & $576.7 \pm 49.5$ & $316.3 \pm 41.4$ & $67.3 \pm 31.1$ \\
\hline pupae & $15.3 \pm 8.6$ & $16.0 \pm 0.6$ & $12.7 \pm 5.7$ & $20.7 \pm 6.5$ & $3.3 \pm 1.8$ \\
\hline Other Diptera & $7.0 \pm 3.1$ & $7.0 \pm 1.2$ & $5.0 \pm 1.5$ & $2.0 \pm 1.0$ & $0.3 \pm 0.3$ \\
\hline \multicolumn{6}{|l|}{ July } \\
\hline Plecoptera & $26.3 \pm 11.9$ & $19.7 \pm 15.7$ & 0 & 0 & 0 \\
\hline Ephemeroptera & $219.0 \pm 100.1$ & $571.3 \pm 217.7$ & $1.7 \pm 0.7$ & $0.3 \pm 0.3$ & 0 \\
\hline Trichoptera & $72.3 \pm 15.1$ & $48.7 \pm 24.3$ & $2.3 \pm 0.9$ & $0.3 \pm 0.3$ & 0 \\
\hline Elmidae & $31.7 \pm 11.7$ & $78.0 \pm 32.3$ & $4.3 \pm 0.9$ & $1.3 \pm 0.7$ & $0.3 \pm 0.3$ \\
\hline Gyrinidae & 0 & 0 & 0 & 0 & 0 \\
\hline \multicolumn{6}{|l|}{ Simuliidae } \\
\hline larvae & $26.3 \pm 10.8$ & $918.3 \pm 569.1$ & $1.3 \pm 0.9$ & 0 & 0 \\
\hline pupae & 0 & $10.3 \pm 7.9$ & 0 & 0 & 0 \\
\hline \multicolumn{6}{|l|}{ Chironomidae } \\
\hline larvae & $565.7 \pm 128.8$ & $1255.3 \pm 194.9$ & $507.7 \pm 38.4$ & $66.3 \pm 13.8$ & $18.0 \pm 4.6$ \\
\hline pupae & $10.7 \pm 4.7$ & $11.7 \pm 5.2$ & $14.7 \pm 3.2$ & $5.3 \pm 2.3$ & 0 \\
\hline Other Diptera & $6.7 \pm 3.2$ & $4.0 \pm 2.6$ & $0.7 \pm 0.7$ & $0.7 \pm 0.3$ & $0.7 \pm 0.3$ \\
\hline
\end{tabular}




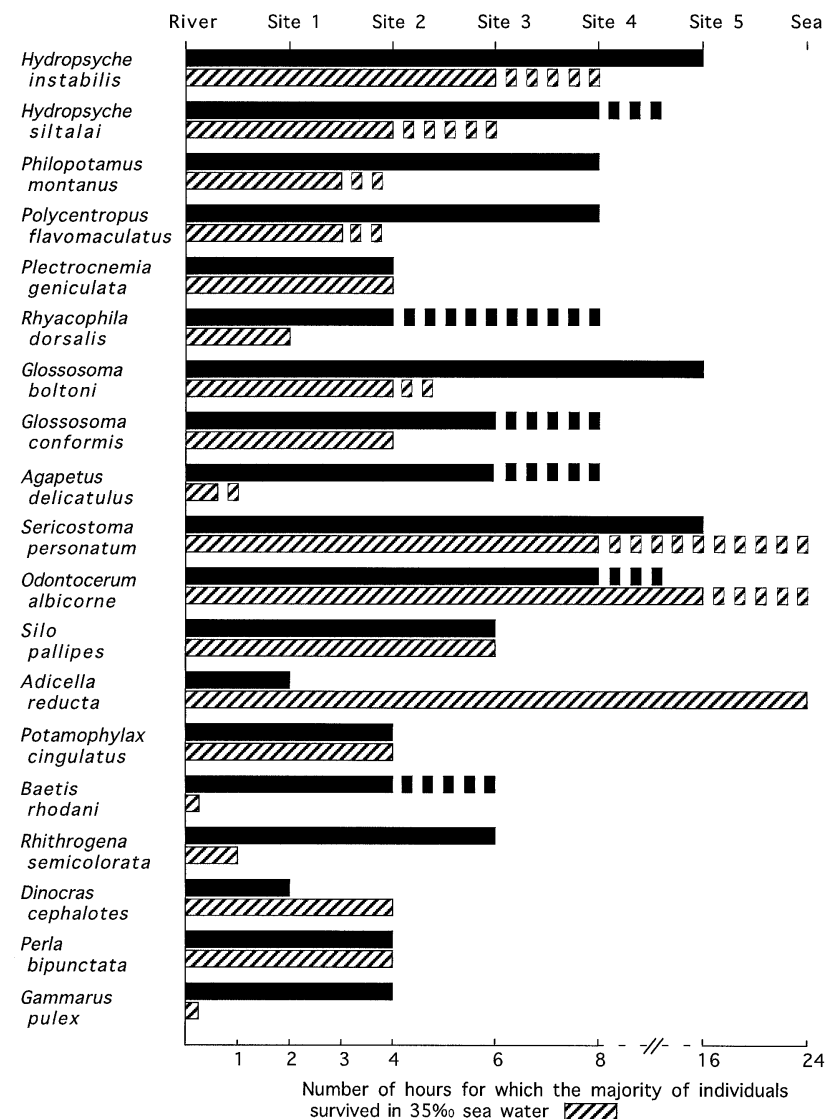

Fig. 2 Comparison of the salinity tolerance (as measured by immersion in 35\% seawater; hatched bars) of the most abundant species of Trichoptera, Ephemeroptera and Plecoptera, with their observed distributional ranges in the Aber Estuary (solid bars).

stonefly nymphs are summarized in Fig. 2. Whereas a number of caddisflies were found as far downstream as site 5, Dinocras cephalotes and Perla bipunctata were confined to the upper estuary. Amongst the Ephemeroptera, Caenis rivulorum was largely confined to site 1 and Baetis rhodani to sites 1 and 2 (it was especially abundant at the latter site in July). Rhithrogena semicolorata was occasionally taken at site 3 . Simulium variegatum occurred commonly (very abundant in July) at sites 1 and 2, and occasionally at site 3 .

\section{Salinity tolerance}

Virtually all individuals of the nineteen species of freshwater insect collected from site 1 survived a $4 \mathrm{~h}$ immersion in $8.75 \%$ o saltwater, although there was some indication of stress (e.g. erratic movement, thrashing of body, abandonment of case) among some of the caddisflies (Table 2). At half-strength (17.5\%o) seawater, although both mayfly species survived up to $1 \mathrm{~h}$, none was alive after $4 \mathrm{~h}$. There was $100 \%$ survival of the small herbivorous stonefly (Nemouridae), and of most of the caddisfly species, although again some showed definite signs of distress after $1 \mathrm{~h}$. Deaths were recorded for Glossosoma conformis and Hydropsyche instabilis. In $26.25 \%$ seawater, there was good survival of the caddisflies Philopotamus montanus, Hydropsyche siltalai, H. instabilis, Sericostoma personatum and Odontocerum albicorne. After $4 \mathrm{~h}$ in full-strength seawater, at least some larvae of the above five species survived, together with at least one individual of four other caddisfly species. In addition, all specimens of the large predaceous stonefly Dinocras cephalotes and just over half of the individuals of the perlid stonefly Perla bipunctata had survived.

In the experiment designed to simulate immersion according to a $24 \mathrm{~h}$ tidal cycle in the Aber Estuary (Table 3), four species of caddisfly survived well (S. personatum, O.albicorne, Potamophylax cingulatus and Adicella reducta). Just under $20 \%$ of the $H$. instabilis larvae survived. Continuous immersion in fullstrength seawater for $24 \mathrm{~h}$ was survived only by a few specimens of S. personatum, O. albicorne and Adicella reducta (Table 4 ).

In several cases, there was good agreement between the distributions of the most abundant lotic species in the estuary and the laboratory-measured maximum number of hours that these insects could survive in full-strength seawater (Fig. 2); for example the occurrence of the caddisflies $H$. instabilis, $S$. personatum and O. albicorne at downstream sites 4 and 5 matched their long immersion tolerance. Conversely, Baetis rhodani had a much shorter immersion tolerance and was largely restricted to upstream sites 1 and 2. However, a correlation analysis applied to the data for eighteen species showed no overall significant relationship ( $r=$ $0.07 ; P>0.5$ ) between immersion tolerance (maximum number of hours survived in $35 \%$ seawater) and longitudinal distribution (greatest distance recorded downstream from site 1).

\section{Discussion}

In the Aber Estuary, saltwater intrusion takes the form of a wedge that moves upstream over the surface of the substrate on a twice-daily cycle. All of the benthic insects described in this study are thus subject to a 
Table 2 Results of the salinity tolerance tests on freshwater-derived insects collected from the Aber Estuary. Survival was measured after a $20 \mathrm{~h}$ recovery period, in river water, immediately after the test period

\begin{tabular}{|c|c|c|c|c|c|c|c|c|}
\hline \multirow[b]{3}{*}{ River taxa } & \multicolumn{8}{|c|}{ Survival after 1 or $4 \mathrm{~h}$ in water of increasing salinity } \\
\hline & \multicolumn{2}{|c|}{$8.75 \%$} & \multicolumn{2}{|c|}{$17.5 \%$} & \multicolumn{2}{|c|}{$26.25 \%$} & \multicolumn{2}{|c|}{$35.0 \%$} \\
\hline & 1 & 4 & 1 & 4 & 1 & 4 & 1 & 4 \\
\hline \multicolumn{9}{|l|}{ Ephemeroptera } \\
\hline Baetis rhodani & $\checkmark$ & $\checkmark$ & $\checkmark$ & $\mathrm{D}$ & $\sqrt{ } \mathrm{M}$ & $\mathrm{D}$ & $\mathrm{D}$ & $\mathrm{D}$ \\
\hline Rhithrogena semicolorata & $\checkmark$ & $\checkmark$ & $\checkmark$ & $\mathrm{D}$ & $\checkmark$ & $\mathrm{D}$ & $\checkmark \mathrm{D}$ & $\mathrm{D}$ \\
\hline \multicolumn{9}{|l|}{ Plecoptera } \\
\hline Dinocras cephalotes & - & - & - & - & - & - & $\checkmark$ & $\checkmark$ \\
\hline Perla bipunctata & - & - & - & - & - & - & $\sqrt{ } \mathrm{M}$ & $\sqrt{ } \mathrm{D}$ \\
\hline small stonefly (Nemouridae) & $\checkmark$ & $\checkmark$ & $\checkmark$ & $\checkmark$ & $\checkmark$ & $\mathrm{D}$ & $\checkmark$ & $\checkmark \mathrm{D}$ \\
\hline \multicolumn{9}{|l|}{ Trichoptera } \\
\hline Rhyacophila dorsalis & $\checkmark$ & $\checkmark$ & $\checkmark$ & $\checkmark$ & $\checkmark$ & $\mathrm{D}$ & $\checkmark$ & $\sqrt{ } \mathrm{D}$ \\
\hline Glossosoma boltoni & $\mathrm{L}$ & $\sqrt{ } \mathrm{L}$ & $\sqrt{ } \mathrm{L}$ & $\sqrt{ } \mathrm{M}$ & - & - & M & LD \\
\hline G. conformis & $\checkmark$ & $\sqrt{ } \mathrm{D}$ & $\sqrt{ } \mathrm{L}$ & LD & $\sqrt{ } \mathrm{L}$ & LD & LM & $\mathrm{D}$ \\
\hline Agapetus delicatulus & $\checkmark$ & $\checkmark$ & - & - & - & - & - & - \\
\hline Philopotamus montanus & $\checkmark$ & $\checkmark$ & $\checkmark$ & $\checkmark$ & $\checkmark$ & $\checkmark$ & $\sqrt{ } \mathrm{M}$ & $\sqrt{ } \mathrm{D}$ \\
\hline Plectrocnemia geniculata & - & - & - & - & $\checkmark$ & $\checkmark$ & - & - \\
\hline Polycentropus flavomaculatus & - & - & - & - & - & - & $\checkmark$ & $\sqrt{ } \mathrm{D}$ \\
\hline Hydropsyche siltalai & $\checkmark$ & $\checkmark$ & $\checkmark$ & $\checkmark$ & $\checkmark$ & $\sqrt{ } \mathrm{M}$ & $\checkmark$ & $\sqrt{ } \mathrm{M}$ \\
\hline H. instabilis & $\checkmark$ & $\sqrt{ } \mathrm{D}$ & $\checkmark$ & $\sqrt{ } \mathrm{D}$ & $\checkmark$ & $\sqrt{ } \mathrm{D}$ & $\checkmark$ & $\checkmark \mathrm{D}$ \\
\hline Potamophylax cingulatus & $\checkmark$ & $\checkmark$ & - & - & - & - & - & - \\
\hline Silo pallipes & $\checkmark$ & $\checkmark$ & - & - & - & - & - & - \\
\hline Sericostoma personatum & $\checkmark$ & $\checkmark$ & $\checkmark$ & $\checkmark$ & $\checkmark$ & $\checkmark$ & $\checkmark$ & $\checkmark \mathrm{M}$ \\
\hline Odontocerum albicorne & $\checkmark$ & $\checkmark$ & $\checkmark$ & $\checkmark$ & $\checkmark$ & $\checkmark$ & $\checkmark$ & $\checkmark$ \\
\hline Adicella reducta & $\checkmark$ & $\checkmark$ & - & - & - & - & $\checkmark$ & $\checkmark$ \\
\hline
\end{tabular}

( $\checkmark$ = individuals were alive and moving; L = larvae had abandoned their cases-a sign of distress; M = moribund, i.e. the animals had stopped moving and had assumed an unnatural stance; $\mathrm{D}=$ dead; combinations indicate some individuals within the test group were in either state; $-=$ sufficient numbers of individuals, between five and ten, were not available for a specific test).

repeated and dramatic change in the osmotic pressure of their environment, although the cycle and degree of change depends on their location along the estuary. Those at site 5, for example, were immersed twice daily, by water of $32-34 \%$ salinity for periods of 3$4 \mathrm{~h}$, whereas those at site 2 were immersed twice daily by saline water on only approximately 10 days per month and for about $0.5-1.0 \mathrm{~h}$ on each occasion. Despite this salt intrusion, high numbers of aquatic insects continuously populated the Aber benthos. Indeed, overall, insects made up $32 \%$ of the numbers of benthic invertebrates collected in the tidal zone (sites 2-5). One factor deemed highly influential in promoting the persistence of larval insects in the Aber Estuary is the presence of a stable and large particle size substratum along most of the bed. Another must be physiological tolerance to salt, as discussed below.

Seasonal comparison of the density data showed

(C) 1998 Blackwell Science Ltd, Freshwater Biology, 39, 411-421 shifts in several taxa, most notably the extension of chironomids down the estuary in April and July, and the concentration of simuliid larvae and mayfly nymphs at site 2 in July. The total freshwater benthos showed a downstream shift between September and December, which was maintained through April and into the summer. The latter was despite peak saltwater inundation (highest tides) in October, November and April. Ironically, in June and July when saltwater intrusion was lowest, the ranges of many aquatic insects had contracted to sites 1 and 2-although this may have been associated with adult emergence. A more detailed discussion of seasonal variation in the longitudinal zonation of the Aber invertebrate fauna and possible causative factors is given by Williams \& Williams (1998).

The salinity tolerance experiments showed that whereas the two common mayflies B.rhodani and 
Table 3 Responses of freshwater-derived insects collected from the Aber Estuary to immersion in $35 \%$ seawater according to a simulated $24 \mathrm{~h}$ tidal cycle

\begin{tabular}{|c|c|c|c|c|c|c|c|}
\hline \multirow[b]{3}{*}{ River taxa } & \multicolumn{7}{|c|}{ Time intervals ( $24 \mathrm{~h}$ total) of immersion cycle } \\
\hline & \multicolumn{4}{|c|}{ Immersion in $35 \%$ seawater } & \multirow{2}{*}{$\begin{array}{l}\text { After } 8 \mathrm{~h} \text { in } \\
\text { river water } \\
12.0\end{array}$} & \multirow{2}{*}{$\begin{array}{l}\text { After a further } 4 \mathrm{~h} \\
\text { in } 35 \% \text { seawater } \\
16.0\end{array}$} & \multirow{2}{*}{$\begin{array}{l}\text { Final condition after } 8 \mathrm{~h} \\
\text { recovery in river water } \\
24.0\end{array}$} \\
\hline & 1.0 & 2.0 & 3.0 & 4.0 & & & \\
\hline \multicolumn{8}{|l|}{ Ephemeroptera } \\
\hline Baetis rhodani & $\mathrm{M}$ & $\mathrm{D}$ & $\mathrm{D}$ & $\mathrm{D}$ & $\mathrm{D}$ & $\mathrm{D}$ & all dead \\
\hline Rhithrogena semicolorata & $\checkmark$ & $? \mathrm{D}$ & $\mathrm{D}$ & $\mathrm{D}$ & $\mathrm{D}$ & $\mathrm{D}$ & all dead \\
\hline \multicolumn{8}{|l|}{ Plecoptera } \\
\hline Dinocras cephalotes & $\checkmark$ & $\checkmark$ & $\checkmark$ & $\checkmark$ & $\checkmark$ & $\checkmark$ & all dead \\
\hline Perla bipunctata & $\checkmark$ & $\checkmark$ & $\checkmark$ & M & $\mathrm{D}$ & $\mathrm{D}$ & all dead \\
\hline small stonefly (Nemouridae) & $\checkmark$ & $\mathrm{M}$ & $\mathrm{D}$ & $\mathrm{D}$ & $\mathrm{D}$ & $\mathrm{D}$ & all dead \\
\hline \multicolumn{8}{|l|}{ Trichoptera } \\
\hline Rhyacophila dorsalis & $\checkmark$ & $\checkmark$ & $?$ & M & $\mathrm{M}$ & $\mathrm{D}$ & all dead \\
\hline Glossosoma boltoni and & & & & & & & \\
\hline G. conformis (combined) & $\mathrm{L}$ & $\mathrm{L}$ & $\mathrm{M}$ & MD & $\mathrm{D}$ & $\mathrm{D}$ & all dead \\
\hline Agapetus delicatulus & - & - & - & - & - & - & \\
\hline Philopotamus montanus & $\checkmark$ & $\checkmark$ & $\checkmark$ & ?M & $\checkmark ?$ & $?$ & all dead \\
\hline Plectrocnemia geniculata & $\checkmark$ & $\checkmark$ & $\mathrm{M}$ & $\mathrm{M}$ & $\checkmark$ & $\checkmark$ & all dead \\
\hline Polycentropus flavomaculatus & - & - & - & - & - & - & \\
\hline Hydropsyche siltalai & $\checkmark$ & $\sqrt{ } ?$ & $\sqrt{ } ?$ & $\checkmark ?$ & $\sqrt{ } \mathrm{D}$ & $\sqrt{ } \mathrm{D}$ & all dead \\
\hline H. instabilis & $\checkmark$ & $\sqrt{ } ?$ & $\checkmark ?$ & $\sqrt{ } ?$ & $\checkmark$ & $\checkmark \mathrm{D}$ & 2 recovered, 9 dead \\
\hline Potamophylax cingulatus & $\checkmark$ & $\checkmark$ & $\checkmark$ & $\checkmark$ & $\checkmark$ & $\checkmark$ & good (only 1 specimen) \\
\hline Silo pallipes & - & - & - & - & - & - & \\
\hline Sericostoma personatum & $\checkmark$ & $\checkmark$ & $\checkmark$ & $\checkmark$ & $\checkmark$ & $\checkmark$ & good \\
\hline Odontocerum albicorne & $\checkmark$ & $\checkmark$ & $\checkmark$ & $\checkmark$ & $\checkmark$ & $\checkmark$ & good \\
\hline Adicella reducta & $\checkmark$ & $\checkmark$ & $\checkmark$ & $\checkmark$ & $\checkmark$ & $\checkmark$ & good \\
\hline
\end{tabular}

$(\checkmark=$ individuals were alive and moving; $\mathrm{L}=$ larvae had abandoned their cases - a sign of distress; $\mathrm{M}=$ moribund, i.e. the animals had stopped moving and had assumed an unnatural stance; D = dead; combinations indicate some individuals within the test group were in either state; - = sufficient numbers of individuals, between five and ten, were not available for a specific test).

R. semicolorata were generally intolerant of much salt and were restricted to the upper part of the estuary, survival of the stoneflies D. cephalotes and P. bipunctata and many of the caddisflies was much better. In particular, S. personatum, O. albicorne and A. reducta, survived not only a simulated $24 \mathrm{~h}$ tidal cycle but also $24 \mathrm{~h}$ of continuous immersion in full-strength seawater. In the first two species, these abilities correlated well with their observed distributions in the estuary. However, A. reducta was not found downstream from site 1. The reason for this, given its superior ability to tolerate salt, is not clear, although Colburn (1988) has suggested that lack of agreement between laboratorymeasured salinity tolerance and field distributions may indicate overriding biotic influences, such as differential predation among field sites. There were, nevertheless, several other good correlations (e.g. H. instabilis, P. geniculata, S. pallipes, P. cingulatus and
P.bipunctata) and poor correlations (e.g. R.dorsalis, G. boltoni and A. delicatulus). One explanation for poor salt-tolerators occurring at downstream sites may be that individuals had been recently transported there by the current and were moribund when collected, although virtually all of the hand-collected specimens, of all species, were noticeably alive. A more plausible explanation may lie with the potential of downstreamoccurring individuals to acclimatize to higher salinities - recall that all test animals were collected from site 1. Indeed, Haage (1969) has shown that the larvae of freshwater and brackishwater populations of the caddisfly Phryganea grandis L. exhibit a preference for the salt levels in their native waters. Larvae raised in freshwater could withstand 5\% saline water, but not $10 \%$, however, larvae raised in brackish water could tolerate $10 \%$ for 29 days. Interestingly, a decrease in water temperature of $10{ }^{\circ} \mathrm{C}$ extended the

(C) 1998 Blackwell Science Ltd, Freshwater Biology, 39, 411-421 
Table 4 Responses of freshwater-derived insects collected from the Aber Estuary to continued immersion in $35 \%$ seawater for $24 \mathrm{~h}$

\begin{tabular}{|c|c|c|c|c|c|c|c|c|}
\hline \multirow[b]{2}{*}{ River taxa } & \multicolumn{7}{|c|}{$\begin{array}{l}\text { Time intervals ( } 48 \mathrm{~h} \text { total) } \\
\text { Condition in } 35 \% \text { seawater }\end{array}$} & \multirow{2}{*}{$\begin{array}{l}\text { Final condition after } 24 \mathrm{~h} \\
\text { recovery in river water } \\
48.0\end{array}$} \\
\hline & 1.0 & 2.0 & 3.0 & 4.0 & 6.0 & 8.0 & 24.0 & \\
\hline \multicolumn{9}{|l|}{ Ephemeroptera } \\
\hline Baetis rhodani & M & ?D & $\mathrm{D}$ & $\mathrm{D}$ & $\mathrm{D}$ & $\mathrm{D}$ & $\mathrm{D}$ & all dead \\
\hline Rhithrogena semicolorata & $\checkmark$ & $? \mathrm{M}$ & $\mathrm{D}$ & $\mathrm{D}$ & $\mathrm{D}$ & $\mathrm{D}$ & $\mathrm{D}$ & all dead \\
\hline \multicolumn{9}{|l|}{ Plecoptera } \\
\hline Dinocras cephalotes & $\checkmark$ & $\checkmark$ & $\checkmark$ & $\checkmark$ & $\checkmark$ & $\checkmark ?$ & $\mathrm{D}$ & all dead \\
\hline $\begin{array}{l}\text { Perla bipunctata } \\
\text { small stonefly }\end{array}$ & $\checkmark ?$ & $\checkmark ?$ & $\checkmark ?$ & $\mathrm{M}$ & M & M & $\mathrm{D}$ & all dead \\
\hline (Nemouridae) & $\checkmark$ & $\mathrm{M}$ & $\mathrm{M}$ & $\mathrm{D}$ & $\mathrm{D}$ & $\mathrm{D}$ & $\mathrm{D}$ & all dead \\
\hline \multicolumn{9}{|l|}{ Trichoptera } \\
\hline Rhyacophila dorsalis & $\checkmark$ & $\checkmark ?$ & $? \mathrm{M}$ & M & MD & $\mathrm{D}$ & $\mathrm{D}$ & all dead \\
\hline \multicolumn{9}{|l|}{ Glossosoma boltoni and } \\
\hline G. conformis (combined) & $\mathrm{L}$ & $\mathrm{L}$ & $\mathrm{L}$ & LM & LM & LM & $\mathrm{D}$ & all dead \\
\hline Agapetus delicatulus & - & - & - & - & - & - & - & \\
\hline Philopotamus montanus & $\checkmark$ & $\checkmark$ & $\sqrt{ } ?$ & $\sqrt{ } ?$ & M & $\mathrm{D}$ & $\mathrm{D}$ & all dead \\
\hline Plectrocnemia geniculata & - & - & - & - & - & - & - & \\
\hline Polycentropus flavomaculatus & - & - & - & - & - & - & - & \\
\hline Hydropsyche siltalai & $\checkmark$ & $\checkmark$ & $\checkmark$ & $\sqrt{ } ?$ & M & ?D & $\mathrm{D}$ & all dead \\
\hline H. instabilis & $\checkmark$ & $\sqrt{ } ?$ & $\checkmark ?$ & $\sqrt{ } ?$ & M & ?D & $\mathrm{D}$ & all dead \\
\hline Potamophylax cingulatus & $\checkmark$ & $\checkmark$ & $?$ & $?$ & M & ?D & $\mathrm{D}$ & dead (only 1 specimen) \\
\hline Silo pallipes & $\checkmark$ & $\checkmark$ & $\checkmark$ & $\checkmark$ & $?$ & ?D & $\mathrm{D}$ & dead ( 1 specimen) \\
\hline Sericostoma personatum & $\checkmark$ & $\checkmark$ & $\checkmark$ & $\checkmark$ & $\sqrt{L}$ & ?L & ?D & 1 recovered, 3 dead \\
\hline Odontocerum albicorne & $\checkmark$ & $\checkmark$ & $\checkmark$ & $\checkmark$ & $\checkmark \mathrm{L}$ & ?L & ?D & 2 recovered, 1 dead \\
\hline Adicella reducta & $\checkmark$ & $\checkmark$ & $\checkmark$ & $\checkmark$ & $\checkmark$ & $?$ & $?$ & good (1 specimen) \\
\hline
\end{tabular}

$(\checkmark$ = individuals were alive and moving; $\mathrm{L}=$ larvae had abandoned their cases - a sign of distress; $\mathrm{M}=$ moribund, i.e. the animals had stopped moving and had assumed an unnatural stance; $\mathrm{D}=$ dead; combinations indicate some individuals within the test group were in either state; - = sufficient numbers of individuals, between five and ten, were not available for a specific test).

tolerance time in all concentrations. The latter could also help explain the downstream shift in total Aber benthos that was associated with falling riverwater temperature (between September and December). It has been noted earlier that mayflies appear to be the freshwater taxon most adversely affected by high levels of salt (Short, Black \& Birge, 1991). Whereas, in salinity tolerance experiments in the present study, the demise of salt-intolerant species probably provided reliable data, although in fairness it should be noted that these experiments assessed survival only over the short term. In the case of the salt-tolerant species, therefore, there is no evidence that individuals survived successfully to adulthood.

At this stage of the research, there is very little information on the behaviour of these aquatic insects in situ. Furthermore, there are few previous studies with which the data presented here can be compared. Sutcliffe (1961) studied the fauna of saltmarsh pools in England and found a few species of euryhaline insects breeding there. In pools in which the maximum salinity reached was $33 \%$, the only aquatic insects found all year round were the midge Chironomus aprilinus, the mosquito Aedes detritus and the beetle Colymbetes fuscus. Another midge, Cricotopus vitripennis, a shore fly, Ephydra riparia, a waterstrider, Gerris thoracicus, and the caddisfly Limnephilus affinis were found to the same salinity level, but were more seasonal in occurrence. In pools in which the salinity was $<10 \%$, Sutcliffe found two different gerrid species, four species of corixid bugs, three beetle species and Chironomus riparius. Clearly, salinity had a major effect on species distribution. Sutcliffe (1960a) suggested that the degree of osmotic independence shown by larvae of E. riparia, A.detritus and C. vitripennis was achievable only by a considerable degree of impermeability to water and salts. He noted that none of these three species had the functional 
anal papillae characteristic of many other aquatic dipteran larvae. Salt taken in through the gut was thought to be excreted from the rectum as a hyperosmotic fluid.

Limnephilus affinis has, along with eighteen other caddisfly species, been found in the Gulf of Finland in water up to $6 \%$ salinity (Silfvenius, 1906). Some thirty-nine species, from several families, were recorded in Gulf of Finland waters with $<2 \%$. Sutcliffe (1960b) demonstrated that L. affinis was capable of surviving for several months in water that contained $26 \%$ salt, but only for a few days in approximately $30 \%$. It was suggested that tolerance of saltwater in this species was achieved via limited drinking of the surrounding water, combined with the ability of the lining of the gut to withstand high salt concentrations and the ability of the larvae to continue to produce hyperosmotic rectal fluid even at such high concentrations (Sutcliffe, 1962).

In a study of fourteen tidepools along the north shore of the St Lawrence River, salinity levels again influenced the assemblages of insects found (Williams \& Williams, 1976). In pools with a salinity $<2.5 \%$ o there were caddisflies (Limnephilus tarsalis and Oecetis sp.), a dragonfly (Aeshna interrupta), together with several species of beetle, corixid and chironomid. Whereas a few L.tarsalis were found in pools with salinity as high as $19.8 \%$, pools above $22 \%$ contained only the shore fly Ephydra subopaca and the marine midges Halocladius and Cricotopus sylvestris. Along the northern Swedish coast, populations of the stonefly Leuctra digitata have high drift rates from streams out into coastal areas with salinities of up to $4.2 \%$ where nymphal development continues to adult emergence (Müller \& Mendl, 1980).

The most extreme examples of aquatic insects adapted to a marine existence include those listed below.

1 Philanisus plebeius, a caddisfly from New Zealand and southeastern Australia, of which the female deposits her eggs into the coelomic cavity of starfishes. After hatching, the larvae leave their host and develop in tidepools (Winterbourn \& Anderson, 1980).

2 The gerrid genus Halobates, which comprises some forty-four species that live on the surface of the oceans, especially in the Indo-Malaysian and Australasian region. Five of these live in the central Pacific Ocean and have no contact with land (Cheng, 1985).

3 The chironomid Pontomyia which completes its life cycle at depths to $30 \mathrm{~m}$ on tropical coral reefs (Bretschko, 1982).

The most significant finding in the survey reported here was that, numerically, aquatic insects represented approximately one-third of the benthic metazoans in the tidal regions of the Aber Estuary. In general, as already noted, insects are believed to be poorly represented in saltwater environments. There are a variety of hypotheses to explain this, but many can be refuted on the grounds that each apparent physical, chemical or physiological barrier to living in saltwater has been overcome by at least one or two species from a variety of insect orders (see the above examples). Theories that propose the exclusion of insects, as a whole, from saltwater environments thus represent an unrealistic tenet. Undeniably, the majority of insects that have been recorded from marine situations have been collected in so-called 'bridging habitats' (e.g. estuaries, saltmarshes, intertidal areas, mangrove swamps, etc.; Cheng, 1976). It has been argued recently, therefore, that rather than insects being fundamentally unsuited to saltwater, we are currently observing the early stages in the spread of insects into marine environments (Williams \& Feltmate, 1992). Clearly, in the Aber Estuary all the insect species found also occurred in purely freshwater parts of the system. In no way, therefore, can they be considered to be 'marine' species. Nevertheless, their ability to tolerate inundation by saltwater attests to changing osmotic, physiological and, possibly, behavioural capabilities. Perhaps there are genotypic differences in the abilities of subpopulations of these freshwater insects to cope with varying salinity, as has been demonstrated recently in the mosquito fish, Gambusia holbrooki (Congdon, 1994). The selective forces promoting such adaptations are the subject of ongoing research.

\section{Acknowledgments}

For access to the Aber Estuary and foreshore we thank the following custodians and property owners: Lady Janet Douglas Pennant, Penrhyn Castle Estate; College Farm, University of Wales, Bangor; the Countryside Council for Wales; the Wildfowler's Club; and the Northwestern and North Wales Sea Fisheries Committee. We are grateful also to Dr Maurice Lock and the School of Biological Sciences, University of Wales, Bangor for providing excellent research facilities. Our

(C) 1998 Blackwell Science Ltd, Freshwater Biology, 39, 411-421 
biggest debt of gratitude, however, goes to Marilyn Smith for her unsurpassed laboratory skills.

\section{References}

Axtell R.C. (1976) Horse flies and deer flies (Diptera: Tabanidae). Marine Insects (ed. L. Cheng), pp. 415-446. North Holland Publishers, Amsterdam.

Bassett D.A. (1967) A Source-Book of Geological, Geomorphological and Soil Maps for Wales and the Welsh Borders (1800-1966). Amgueddfa Genedlaethol Cymru, Cardiff.

Bretschko G. (1982) Pontomyia Edwards (Diptera: Chironomidae), a member of the coral reef community at Carrie Bow Bay, Belize The Atlantic Barrier Reef Ecosystem at Carrie Bow Bay, Belize I. Structure and Communities (eds K. Rutzler and I. G. MacIntyre), pp. 381-385. Smithsonian Contributions to Marine Science 12., Washington, D.C.

Brown E.H. (1960) The Relief and Drainage of Wales, a Study in Geomorphological Development. University of Wales Press, Cardiff.

Cheng L. (ed.) (1976) Marine Insects. North Holland Publishers, Amsterdam.

Cheng L. (1985) Biology of Halobates (Heteroptera: Gerridae). Annual Review of Entomology, 30, 111-135.

Colburn E.A. (1988) Factors influencing species diversity in saline waters of Death Valley, USA. Hydrobiologia, 158, 215-226.

Congdon B.C. (1994) Salinity-related fitness differences amongst GPI genotypes in the mosquitofish Gambusia holbrooki (Poeciliidea: Teleostei). Biological Journal of the Linnean Society, 53, 343-352.

Dobson T. (1976) Seaweed flies (Diptera: Coleopidae). Marine Insects (ed. L. Cheng), pp. 446-464. North Holland Publishers, Amsterdam.

Gullan P.J. \& Cranston P.S. (1994) The Insects: An Outline of Entomology. Chapman \& Hall, London.

Haage P. (1969) Salinity preference and tolerance of caddis larvae (Trichoptera). Opuscula Entomologica, 34, 73-89.

Healey M.C. (1982) Juvenile Pacific salmon in estuaries: the life support system. Estuarine Comparisons (ed. V.S. Kennedy), pp. 315-341. Academic Press Inc., London.

McIntyre A.D. \& Eleftheriou A. (1968) The bottom fauna of a flatfish nursery ground. Journal of the Marine Biological Association of the United Kingdom, 48, 113-142.

Mees J., Dewicke A. \& Hamerlynck O. (1993) Seasonal composition and spatial distribution of hyperbenthic communities along estuarine gradients in the Westerschelde. Netherlands Journal of Aquatic Ecology, 27, 359-376.

Müller K. \& Mendl H. (1980) On the biology of the stonefly species Leuctra digitata in a northern Swedish coastal stream and its adjacent coastal area (Plecoptera: Leuctridae). Entomologia Generalis, 6, 217-223.

Short T.M., Black J.A. \& Birge W.J. (1991) Ecology of a saline stream: community responses to spatial gradients of environmental conditions. Hydrobiologia, 226, 167178.

Silfvenius A.J. (Siltala) (1906) Zur Trichopteranfauna des Finnischen Meerbusens. Acta societas Fauna Flora fennici, 26, 1-21.

Stocks J. (1988) The human impact upon water quality: a case study of three North Wales streams. BA (Hons) thesis, Geography, North Staffordshire Polytechnic.

Sutcliffe D.W. (1960a) Osmotic regulation in the larvae of some euryhaline Diptera. Nature, London, 187, 331-332.

Sutcliffe D.W. (1960b) Observations on the salinity tolerance and habits of a euryhaline caddis larva, Limnephilus affinis Curtis (Trichoptera: Limnephilidae). Proceedings of the Royal Entomological Society of London, 35, 156-162.

Sutcliffe D.W. (1961) Salinity fluctuations and the fauna in a salt marsh with special reference to aquatic insects. Transactions of the Natural History Society of Northumberland and Durham, 14, 37-56.

Sutcliffe D.W. (1962) Studies on salt and water balance in caddis larvae (Trichoptera). Journal of Experimental Biology, 39, 141-160.

Williams D.D. \& Feltmate B.W. (1992) Aquatic Insects. C.A.B. International, Wallingford, Oxford.

Williams D.D. \& Williams N.E. (1976) Aspects of the ecology of the faunas of some brackishwater pools on the St. Lawrence North Shore. Canadian Field-Naturalist, 90, 410-415.

Williams D.D. \& Williams N.E. (1998) Seasonal variation, export dynamics, and consumption of freshwater invertebrates in an estuarine environment. Estuarine and Coastal Shelf Science, in press.

Winterbourn M.J. \& Anderson N.H. (1980) The life history of Philanisus plebeius Walker (Trichoptera: Chathamiidae), a caddisfly whose eggs were found in a starfish. Ecological Entomology, 5, 293-303.

(Manuscripted accepted 22 October 1997) 